\title{
The feasibility study of introducing crowdfunding into the PPP model of
}

\section{profit-making enterprises}

\author{
Zhang ting Chen jiaxin
}

Keywords: PPP, Crowdfunding, Financing

\begin{abstract}
In recent years, the 3P (PPP) model has played an important role in the financing and operation of public infrastructure projects as a new type of financing. However, the PPP model has disadvantages such as high financing cost, certain franchise monopoly and complex transaction structure. The crowdfunding is developing gradually as a new financing model, in this paper, the feasibility of introducing crowdfunding into PPP financing mode of profit-making enterprises is analyzed.
\end{abstract}

\section{Introduction}

In 2014, the ministry of finance proposed to broaden the financing channels ofurbanization construction, promote the transformation of government functions, perfect the financial investment and management mode, as soon as possible to promote the development of the government and social capital cooperation pattern of institutional system [1]. The PPP (Public Private Partnership) as a"benefit-sharing, risk-sharing and full cooperation" partnership between public and Private receives vigorous promotion by the state council and the ministry of finance. In 2015, the state council put forward actively promoting cooperation between government and social capital (PPP) mode and introduce franchise method for infrastructure and public utilities to fully activate social investment [2]. Li keqiangproposed to actively promote the PPP model in infrastructure and other areas in government's work report. The annual budget report of the ministry of finance proposed the construction of the PPP demonstration project to unleash the potential of social investment. PPP model, the government and social capital cooperation, is a project operation model in public infrastructure. In this model, private enterprises and private capital are encouraged to cooperate with the government to participate in the construction of public infrastructure. The PPP project relies on the sharing of interests and risk-sharing partnerships, which can effectively reduce the overall cost of the project and achieve higher economic efficiency, helping to increase funding for infrastructure projects, improving the financial soundness of the public sector and private sectorand improving the quality of infrastructure/public services.

The social capital cost of financing of a project includes not only factors such as interest rate ,what is more important is to consider the whole society value of the project, including project specific risk, project overall performance of ascension, and the corresponding capital innovation ability. At the same time, compared with the public sector, the business enterprises, especially some of the private sectors, have low credit level of recognition, therefore the PPP project financing costs for the business enterprise is huge.Moreover,thechronicity and complexity of the PPP contract determines that the government has a small space of options for profit-making enterprises, the high bid cost for private enterprise also led to the existence of the big barrier between them and the PPP.

Crowdfunding is the network business model came to stage in 2009. It is a kind of financing innovation of science and technology, refers to a group of people provide funding support through 
the Internet for a project or a creative funding to replace financing entity or individual such as Banks, venture capital, angel investors which are accepted by all[3]. Crowdfunding as a financing model is cost-effective and efficient, including low start-up costs, low sales costs, and low transaction costs. Among many kinds of the crowdfunding, the most common way profit-making enterprises use mostis to raise money based on rewards or advanced sales (reward -based or Pre - sales) andon the equity of the raise (equity - based).

The financing that the project sponsors raise through crowdfunding will provide a broader implementation space and more long-term development pathfor the traditional PPP model .

\section{The feasibility analysis of crowdfunding is introduced in PPP mode of profit-making enterprises}

since 2014, the state council and related ministries and commissions densely issued a number of policy documents in the government and social capital cooperation to promote and guide the PPP projects. At the same time, the local government also launched the PPP demonstration and pilot projects as required. So far, the PPP reform has been in place for three years, but the private capital which can truly participate in the PPP projectis only a handful. The PPP project presents a situation "many contacts, few signings, strong wills and difficult ground". Therefore, the state has introduced policy support and guide private capital to participate in PPP. Such as the "state council's decision on deepening the reform of the budgetary management system" and the "state council's opinions on strengthening the management of local government debt". The government wants to better implement the PPP project financing and encourage innovative financing management and financing products of financial institutions. Crowdfunding is a new product of the times and has great potential for development, those policies will provide the basis for crowdfunding to be introduced as financing arrangements for the PPP project.

The unique attributes of thePPP project provide a strong sense of trust for the participants. Whether or not there is trust is one of the main reasons why the public has decided whether to participate in a crowdfunding campaign, which determines whether crowdfunding will succeed. At present, the crowdfunding is still in its development stage, it is not mature and it has not set up an industry standard. In this case, the risk of non-standardization and fraud risk is likely to occur. In addition, legal and regulatory mechanism is imperfect so that many investors do not want to believe and participate in the raise because of asymmetric information. The PPP project's own characteristics are precisely the ones that make up for these problems. For example, the PPP project is a public-private partnership, and the government is involved in the whole process, so the PPP project has the credibility of the government as a guarantee. The government, as a provider of public goods and services, will be responsible for the smooth construction and operation of these projects. In the PPP model, the involvement of government authorities goes throughout the process of project identification, project preparation, project procurement, project execution, and project transition. Therefore, with the government's credibility and full participation, the PPP investment is more credible for investors. In order to attract social capital investment to participate in, to keep the PPP pattern of sustainable development, to reduce pressure on fiscal expenditure and to improve the level of the supply of public goods or service and efficiency, government departments will certainly guarantee the normal profits of social capital.

\section{The crowdfunding will meet some of the financing requirements of the PPP project}

The growth of the crowdfunding is extremely fast and its potential is huge. According to a report by 
the world bank, China is expected to raise $\$ 46$ billion to $\$ 50$ billion by 2025, with a global scale of $\$ 96$ billion. This also partly proves that the Chinese people are getting rich and have a lot of money to invest in. Crowdfunding, as one of the most accessible forms of private capital, enables rapid concentration of social capital and provides strong financial support for PPP projects.

Crowdfunding is characterized by low financing cost and high efficiency. The high cost of the financing cost is determined by the high demand and complex financing structure of the PPP project. Since the object of crowdfunding is the most widely public and Internet financial modeis informative and easily accessed, crowdfunding can greatly reduce transaction costs, eliminate the financial intermediaries cumbersome process; The market is sufficiently efficient that it is close to the non-financial intermediation state described by the general equilibrium theorem, so that it can save a large amount of intermediary funds and time costs [5].

Crowdfunding has four basic types, as a new mode of financing,it has not finalize the design.Because of its flexibility, adaptability, it is still in the developmentto adapt to the needs of different projects, develop a new type, new form and adjust flexiblyits threshold to adapt to the characteristics of the project [6]. All of these features help to broaden the PPP's financing channels and ways.

Because the crowdfunding has network as its platform and the user is wide, crowdfunding can promote the propaganda of the PPP project. On the other hand, because the public product or service itself will attract the public attention, it will even become a very popular topic, which can reduce the cost of the propaganda, attract more people to participate in, to enhance the suggests the possibility of success [7].

\section{Conclusion}

PPP and crowdfunding are two types of financing methods which have their own attributes, and the main characteristics of PPP are the government participation, and the main characteristics of the crowdfunding are the participation of the public. The PPP model in today's era has a number of flaws and limitations, such as the high level of financing and the difficulty of making loans for private companies to participate in PPP projects. The undisciplined and arbitrary behavior of local government departments has caused private enterprises to lose their enthusiasm for participating in PPP projects. And crowdfunding is a whole new way of financing, the rapid inflow of social capital is a great way to solve the PPP financing problem. But it is also because it is in the growth stage, and there are many problems. Although Different from the traditional public welfare undertakings, profit-making enterprises have relativelyfast investment return rate, satisfying the problem that participators cares for most, namely the return on investment. But because the system of crowdfunding is incomplete, it is difficult to mobilize the public's enthusiasmto participate in , and the combination of the two needs to be constantly accommodated. Therefore, the introduction and improvement of relevant policies are very important. If the related problem of the raise can be saved, making the raise a more reliable and perfect the mode of financing, the combination of the PPP and the raise will be bound to bring about a new financing trend.

\section{References:}

[1], "Information about the use of government and social capital cooperation model" (2014) 76

[2], The notice of the development reform commission on deepening the key work on the reform of the economic system in 2015, issued by China NDRC (2015) 26

[3]Li xuejing The development of crowdfunding models [J]. Journal of the Shanghai institute of 
finance, 2013 (6) : 73-79.

[4]Wang shaungshaung What is the biggest value of the crowdfunding campaign?

[5] Kong fan, Xu changxin, new.The "crowdfunding" mode of the landowners' financing model [J]. Journal of east China jiaotong university, 2014 (5) : 30-36.

[6]Finance ministry. The Treasury Department's notice on the promotion of the use of government and social capital cooperation models [S]. 2014.

[7]Finance ministry. Information on the operational guidelines for government and social capital cooperation [S].2014.

\section{Author introduction:}

Zhang Ting (1996 -), female (Han), Mudanjiang, Heilongjiang, undergraduates of Grade 2014 in Financial Management of Hohai University, mainly engaged in the financial management of financial research.

Chen Jiaxin(1996 -), male (Han), Nantong, Jiangsu, undergraduates of Grade 2014 in International Economy and Trade of Hohai University, mainly engaged in the international trade research.

Post: Hohai UniversityNo. 8. Focheng West Road, Jiangning, Nanjing, Jiangsu

Receiver: Zhang Ting

Phone number 15195890933

(Hohai university business school, Nanjing 21000) 